\title{
Did Major Impacts Affect Sedimentologic/Sequence-Analytical Pattern of the Early Palaeozoic Sedimentary Systems of Jordan, Arabian Plate?
}

\author{
Werner Schneider ${ }^{1}$, Elias Salameh ${ }^{2}$ \\ ${ }^{1}$ Im Ziegenförth 15, D-38108 Braunschweig, Braunschweig, Germany \\ ${ }^{2}$ University of Jordan, Amman, Jordan \\ Email: schneiderolaf@hotmail.com, salameli@ju.edu.jo
}

Received July 31, 2012; revised August 29, 2012; accepted September 28, 2012

\begin{abstract}
Based on profound sequence-analytical data of the early Palaeozoic sedimentary systems of Jordan, Arabian Plate, a correlation attempt is proposed with regard to possible major impact events after Price. His methodological concept tells that abrupt changes of both direction and speed of plate motion would indicate such convulsion processes as occurred on: 550 Ma, $526.5 \mathrm{Ma}, 514 \mathrm{Ma}$, 456/455 Ma and 441 Ma. Referring to the fact that major impacts may trigger, respectively influence, exogenic and endogenic processes on an over-regional, even global, extent, this paper put the "sensitive” geological setting of Jordan at the Arabian Platform's margin into focus. That mainly concerns the early Palaeozoic coastlines as to sea level change as well as the Jordan Valley Rift as being possibly to susceptible for tectonic re-activation changes of both direction and speed of plate motions would indicate such convulsive processes as occurred on: $550 \mathrm{Ma}, 526.5 \mathrm{Ma}, 514 \mathrm{Ma}, 502 \mathrm{Ma}, 456 / 455.4 \mathrm{Ma}$, and following triggering of magmatism at the Precambrian/Cambrian boundary. The following phenomena are taken into account: Faulting and magmatism triggered along the Jordan Valley Rift (Wadi Araba) in connection with the Pan-African Orogeny, anoxic sediments, temporary high detrital input onto the adjoining stable platform from Gondwana hinterlands, and significant chemical weathering in the Gondwana source areas by intensive acid (nitric) rain directing mineral content variation in the "Nubian Sandstones (e.g. feldspar, kaolinite/dickite, tourmaline)”.
\end{abstract}

Keywords: Sequence-Analysis; Impacts; Plate Tectonics; Anoxic Sediments; Jordan

\section{Introduction}

The following citations are thought to be an introduction to opinions expressed by outstanding scientists' concerning the new science of cratering geology. They may serve as references to the subject of meteoritic impacts and their further geologic implications. Surprisingly, there is evidence for a remarkably high coincidence of the radiometric ages of both sequence-analytical data (e.g. MFS, SB) and Price's events.

Critically regarding the role of analytical error of radiometric ages, this paper reveals an approach to geoscientific "boundary dispute".

"Acceptance of the "Rare Event" as a viable geological agent does not reintroduce the preternatural into Geology. It does, however, remove certain, and possibly important happenings from the realm of rigid scientific analysis," A shocking realization to any modern scientist [1].

"The recognition of the sedimentologic consequences of "Convulsive Events" poses a special challenge to Sedimentary Geologists. Meeting this challenge will al- most certainly demonstrate that "Convulsive Geologic Events have greater relevance to the sedimentary record than has been previously recognized".

Why is there no physical evidence for such impacts other than the Cretaceous-Tertiary boundary clay? Part of the problem undoubtedly lies with preservation.

"But the effects of major impacts are likely to be of such broadly regional, even global, extent that one would intuitively expect at least fragmentary preservation of its consequences [2]”.

"Especially the search for impact debris in the Phanerozoic sedimentary rock record has vast potential to pinpoint some of those large impact events [3]”.

Based on profound sequence-analytical data, this paper directly deals with the open questions asked in the quotations cited above.

Since Sharland [4] submitted a synthesis of the sequene sctratigraphy of the Arabian Plate, followed by Haq \& Al-Qahtani [5] who published two cycle charts of the regional sea-level fluctuations on the Arabian Platform, it was a challenge to incorporate sequence-analytical 
data of the early Paleozoic systems of Jordan what satisfyingly shows remarkable coincidences to these charts [6].That was not self-evident, since Haq \& Al-Qahtani [5] could benefit from a huge stratigraphic and radiometric data pool of the Near East and Middle East Oil and Gas Industries while we in Jordan, worked with surface outcrops by using macrofossils (trilobites, brachiopods, graptolites) and trace fossils (Cruziana) as time and environmental markers.

The Arabian Infracambrian extensional system, 600 540 Ma [7] shows the geological setting of Jordan as the north-westernmost part of the Arabian Plate, close to the adjacent Jordan Valley Rift and an assumed triple junction (Figures 1 and 2).

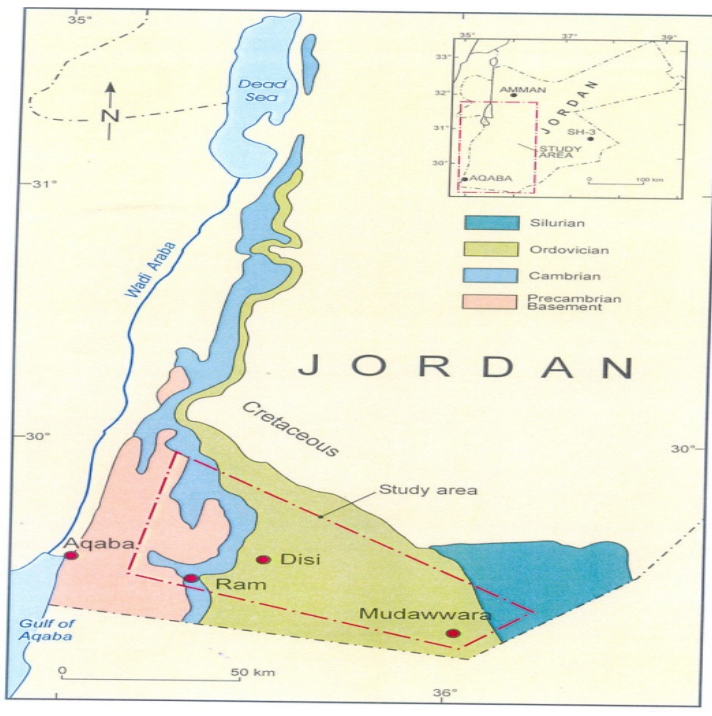

Figure 1. Study area of the early Palaeozoic.

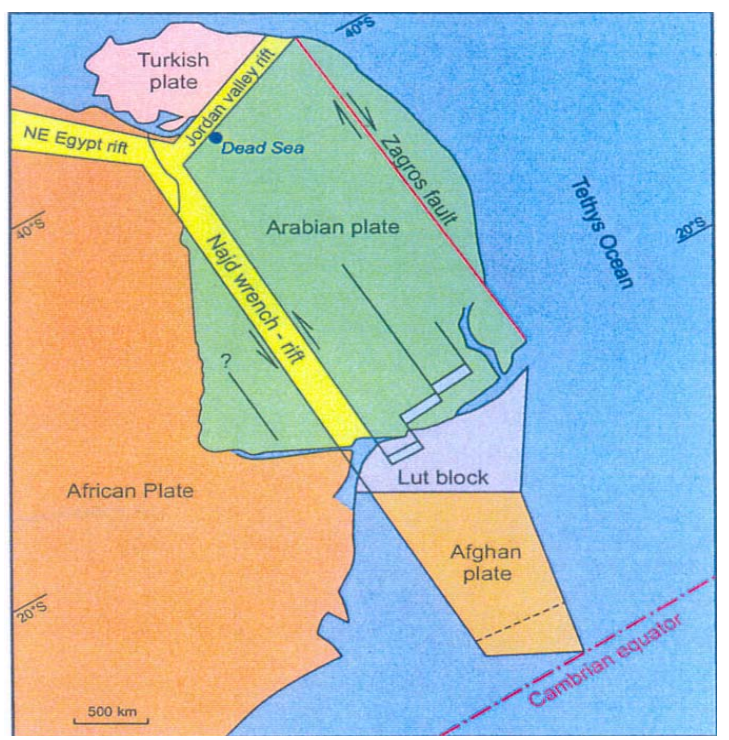

Figure 2. Arabian Infracambrian extensional sedimentary systems of Jordan and location extensional system, 600 540 Ma of well SH-3, Wadi Sirhan.
The data of Haq \& Al-Qahtani [5] are based on epiand peri-platform sequence-stratigraphic studies. They show sedimentary on-lap pattern on the margins of the Arabian Plate, largely at second-order cycle level, and are compared to eustatic data.

The Early Palaeozoic coastlines of Jordan appear as useful for such correlation, since even ingressions of small extent are generally well documented by Cruzianabearing mudstones interbedding the gigantic input of "Nubian Sandstone" (Figure 3, Table 2, [6] ), whose source areas were located south-eastward in the Gondwana hinterlands.

During the Cambrian through the Early Silurian periods, eustasy may have been the most significant controlling factor for sedimentary pattern when long-term trends in both regional and global sea-level curves show high similarities.

The radiometric ages of the "Maximum Flooding Surface" MFS: [8] and the "Sequence Boundaries" = "Erosive Unconformities"; SB: [9] had been re-calibrated to the new (GTS 2004) time scale [5] Applying these data, there may be recognized a remarkable coincidence of sealevel fluctuations along Jordan's paleo-coastlines and those of the Arabian Plate at all (Figure 4).

FORTRAN 77-programs for plotting coastlines and bathymetric data. It contains Throughout the last 40 years it has increasingly become evident that major impacts may have, in addition to mega-volcanic eruptions, an important influence on sedimentologic pattern, like the formation of oxygen-deficient shales and high energy sediments, extremely high sedimentation rates by gigantic clastic input etc. (e.g. [2]) Thus, "sensitive” coastlines as having been existed in Jordan are preferably susceptible to transgression/regression interplays possibly triggered by convulsive events.

The highly differential chronostratigraphic and sequence-analytical data of the Arabian Plate challenge a correlation attempt using comparingly precise data of major impacts that occurred throughout the Early Paleozoic period. Price [10] recovered such major impact events by using two plate tectonic parameters: (a) an abrupt change in direction and (b) an abrupt change of speed of plate motions as well. He used the ATLASSystem (version 3.3) developed by A. Smith and coworkers at Cambridge University, England, as mapping and global reconstruction system for the P. C., in order to design maps and tracks of the movement of continental bodies or individual islands through various periods in the Phanerozoic.

Thus, the ATLAS-System represents a map-making package comprising two EULER rotations and a variety of utilities for creating paleogeographic reconstructions for the last $600 \mathrm{Ma}$; it provides estimates of the past position of present-day shaped coastlines [10]. 


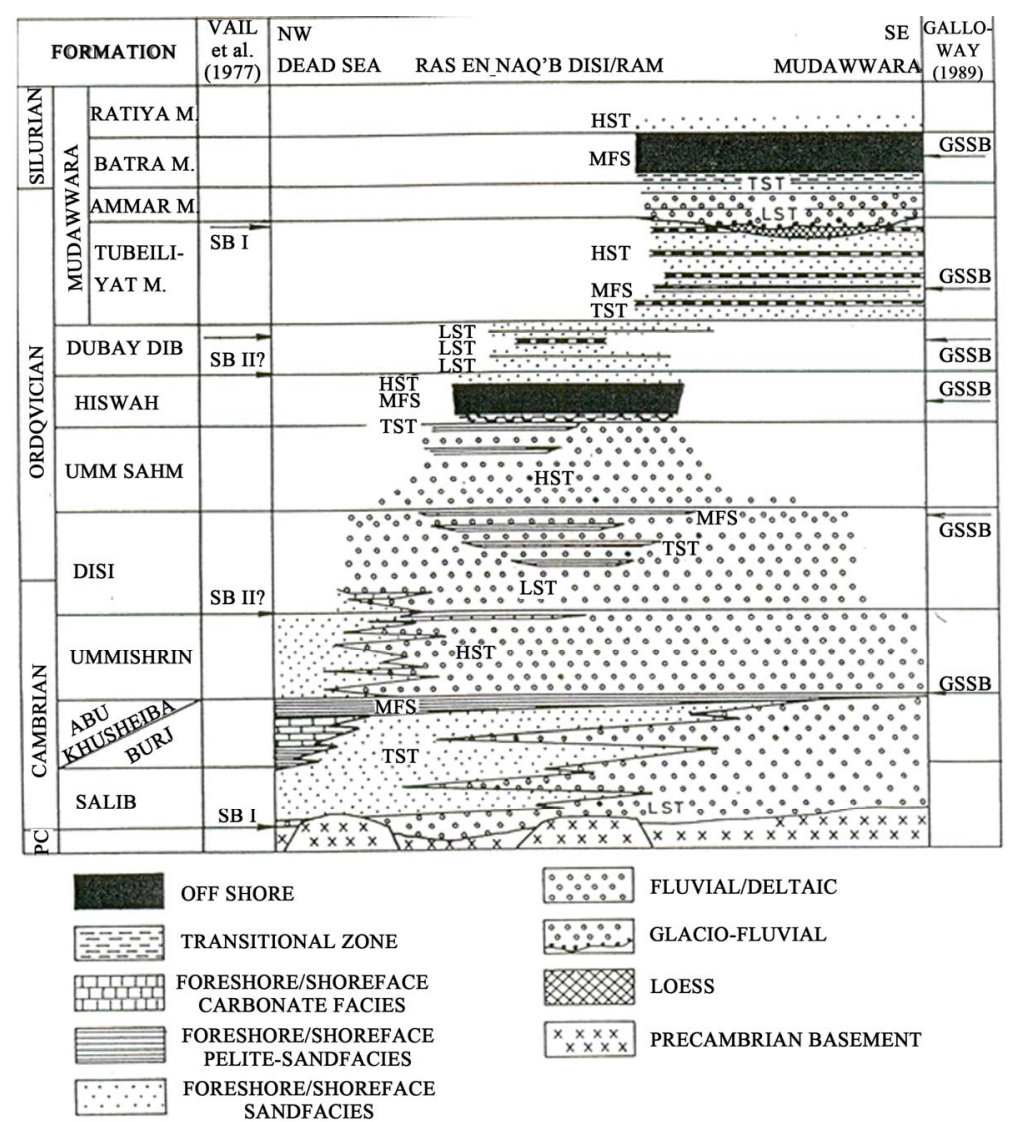

Figure 3. Sequence analytical model of the early Paleozoic sedimentary systems of Jordan.

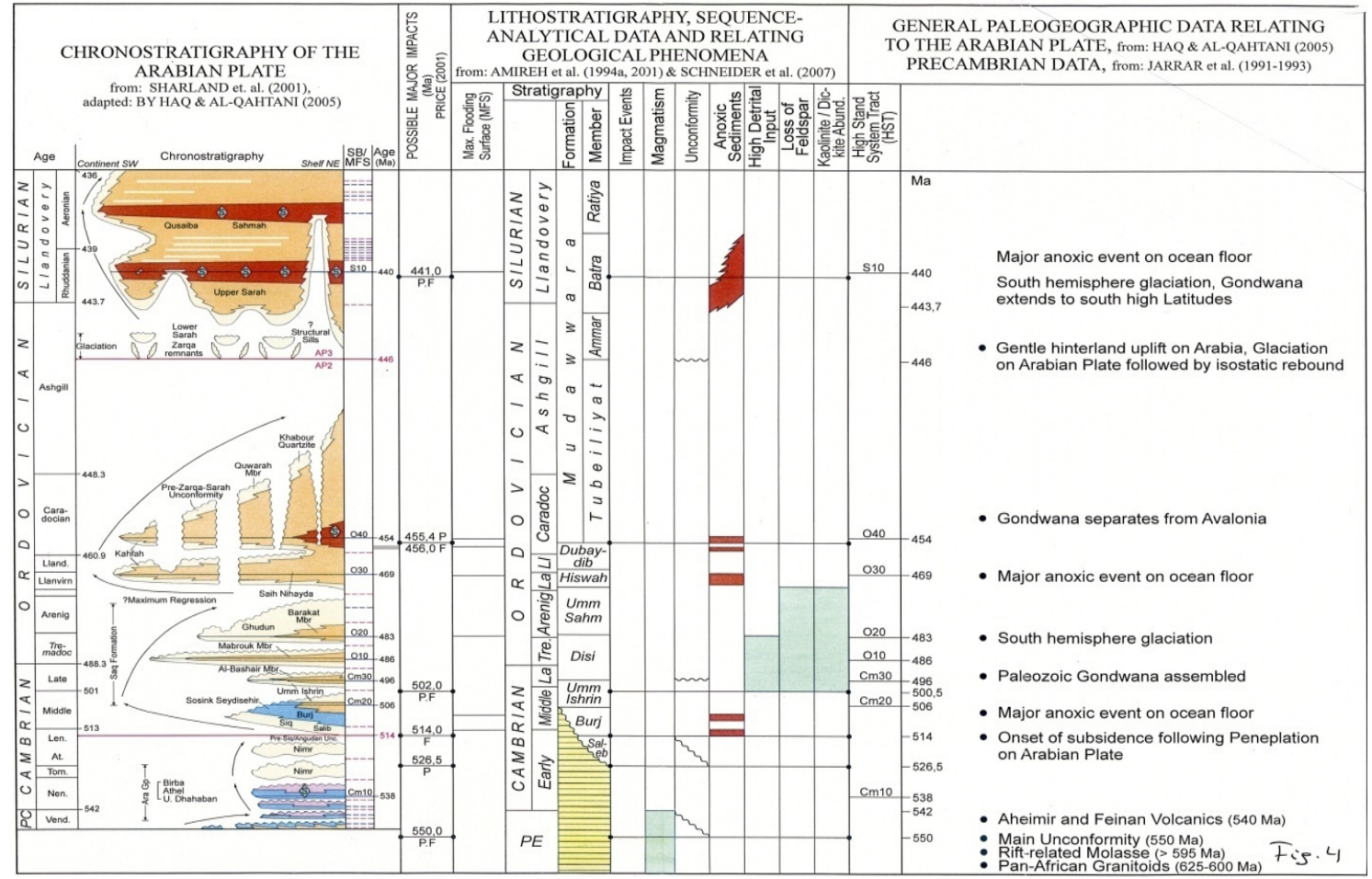

Figure 4. Compilation of chronostratigraphic and sequence-analytical data, possible major impact events, and relating geological pattern throughout the Early Palaeozoic Period of Jordan, Arabian Plate. 
Table 1 lists up the major impacts after Price for the period 600 - $310.5 \mathrm{Ma}$, with regard to Fennoscandia (F) and the Pacific realm (P). The impact event ages of both areas are the same or close together. From Figure 4 a high grade of coincidence with stratigraphic boundaries becomes obvious. Figures 5 (a) and (b) show the plate tectonic motion tracks of both areas for the according time interval.

In the following, sequence-analytical data of Jordan respectively the Arabian Plate at all, will be checked on coincidence with the radiometric ages of the major impact events that could have occurred during the Early Palaeozoic period, according to Price's concept.

\section{Results}

\subsection{Sequence-Stratigraphic Ages and Major Impact Event Ages: Coincidences}

Figure 4 compiles on its left side the chronostratigraphic and sequence-analytical data of the Arabian Plate, and the radiometric ages of possible major impact events relevant and related to the plate tectonic motion tracks of Fennoscandia (F) and of the Pacific realm (P). In the middle

Table 1. Major impact events throughout the period 550 310.5 Ma relating to Fennoscandia (A) and the Pacific realm (B) (Hawaii), Price (2001).

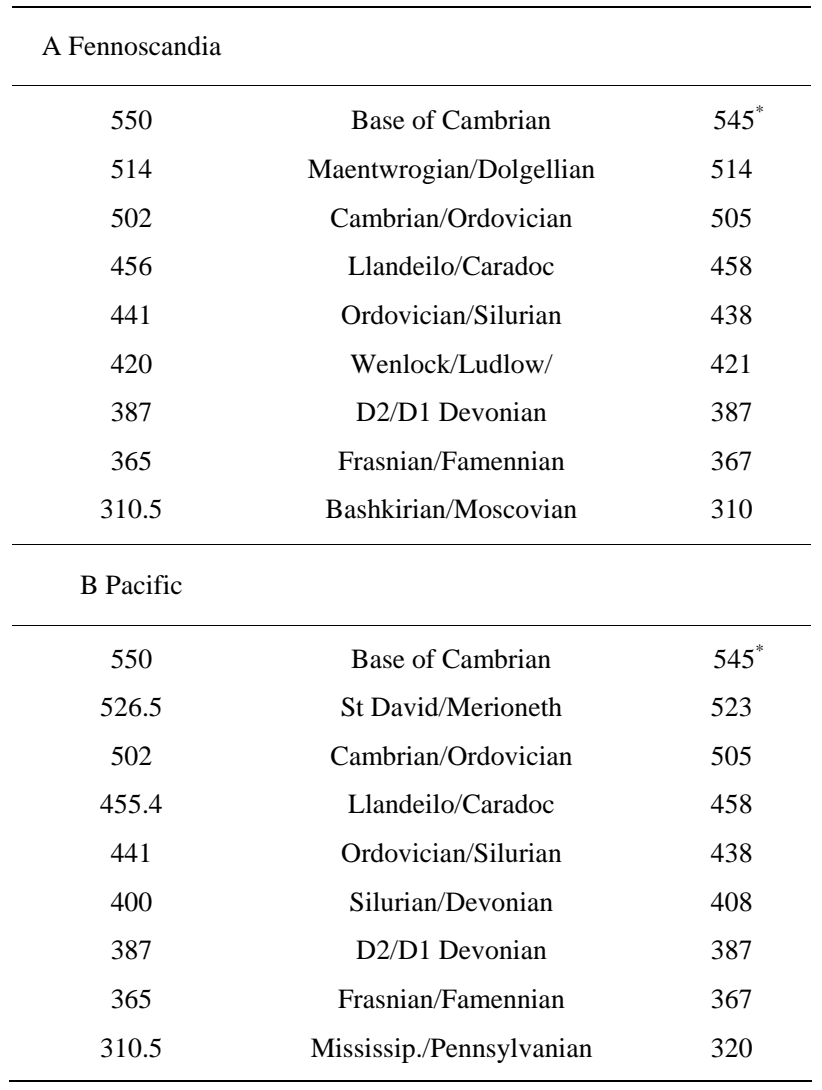

*Base of Cambrian "moved” from 600 Ma to 545 Ma. column the lithostratigraphy, sequence-analytical data of the early Palaeozoic systems of Jordan, and pos- sible impact-related geological phenomena encountered in surface outcrops of southern Jordan, are listed up as: magmatism, unconformities (SB), anoxic sediments, extremely high detrital input, and significant mineralogical changes relating to total loss of feldspar and high amounts of kaolinite/dickite (compare [5]). Finally, the High Systems Tracts (HST), and major tectonic and climatic events on and around the Arabian Plate are added.

According to Table 2, the relevant possible impact event effects upon the sedimentary systems will be commented as follows (see Figure 4).

\subsubsection{Event: 550 Ma (F, P)}

A regional Intra-Proterozoic unconformity appears within the crystalline Pan-African Basement at 600 Ma [11]. Along Wadi Araba, the Aheimir and Feinan Volcanics overlying elder magmatites and clastics (Figure 6), reveal ages ranging from 550 - $540 \mathrm{Ma}$ [12] close to the possible impact event and approximately coinciding with the Precambrian/Cambrian boundary (542 Ma).

On the Arabian Plate, younger carbonate rocks (oilprone source rocks) house a MFS (Cm 10) yielding an age of $538 \mathrm{Ma}$. Sequence-analytical data prior to $550 \mathrm{Ma}$ are not available from the chart of Haq \& Al-Qahtani [5].

\subsubsection{Event: 526 Ma (F)}

This event falls into the Lower Cambrian period when the Main Unconformity (SB) in Southern Jordan developed (540 - $514 \mathrm{Ma}$ ). According to the existing paleorelief, that unconformity, from West to East, climbs up from the base of the Salib F. at Wadi Abu Barqa (Figure 6) to the Middle/Upper Cambrian sandstones of the

Table 2. Possible major impact event ages and sequenceanalytical data (MFS, SB) for the Early Paleozoic sedimentary Systems of Jordan, Arabian Plate.

\begin{tabular}{|c|c|c|}
\hline $\begin{array}{l}\text { Impact event age } \\
\text { (Ma) [5] }\end{array}$ & $\begin{array}{c}\text { Sequence-analytical data of } \\
\text { Jordan [6] }\end{array}$ & $\begin{array}{c}\text { Sequence-analytical } \\
\text { data of the Arabian } \\
\text { Plate [5] }\end{array}$ \\
\hline $441(\mathrm{P}, \mathrm{F})$ & $\begin{array}{l}\text { MFS, oil shale following } \\
\text { glaciation (446 Ma) }\end{array}$ & MFS, oil shale \\
\hline $455.4 / 456(\mathrm{P}, \mathrm{F})$ & $\begin{array}{c}2 \text { MFSs in transition zone of } \\
\text { Dubaydib F./Tubeiliyat M. } \\
\text { boundary }\end{array}$ & MFS, oil shale \\
\hline $502(\mathrm{P}, \mathrm{F})$ & $\begin{array}{l}\text { SB, onset of high detrital } \\
\text { input }\end{array}$ & SB \\
\hline $514(\mathrm{~F})$ & $\begin{array}{c}\text { SB, MFS, onset of anoxic } \\
\text { sediments, L./M. } \\
\text { Cambrian }\end{array}$ & $\begin{array}{l}\text { SB: Pre-Sic Angudan } \\
\text { Unconformity }\end{array}$ \\
\hline $526.5(\mathrm{P})$ & SB, clastic onset & SB \\
\hline $550(P, F)$ & $\begin{array}{l}\text { SB, main unconformity, } \\
\text { Wadi Araba volcanism }\end{array}$ & SB?, MFS? \\
\hline
\end{tabular}


Umm Ishrin F. at Wadi Rum (Figure 7). The clastic sedimentation of the Salib F. set on with basal conglomerates, and continues with arkosic sandstones of low maturity upon the Pan-African Basement. For Wadi Araba, Jarrar
$[11,12]$ ascertained an age period of the Main Unconformity on 540 - $530 \mathrm{Ma}$.

On the Arabian Plate, the possible impact event happened in between two SBs.

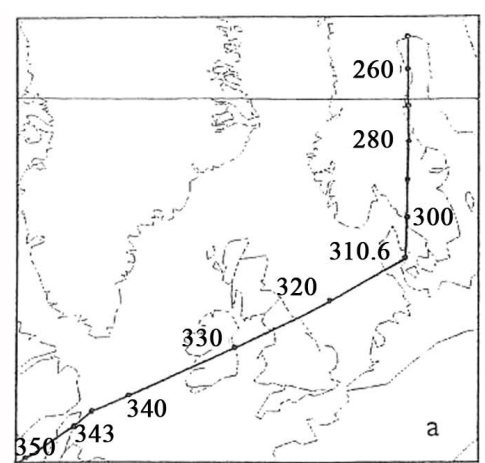

A
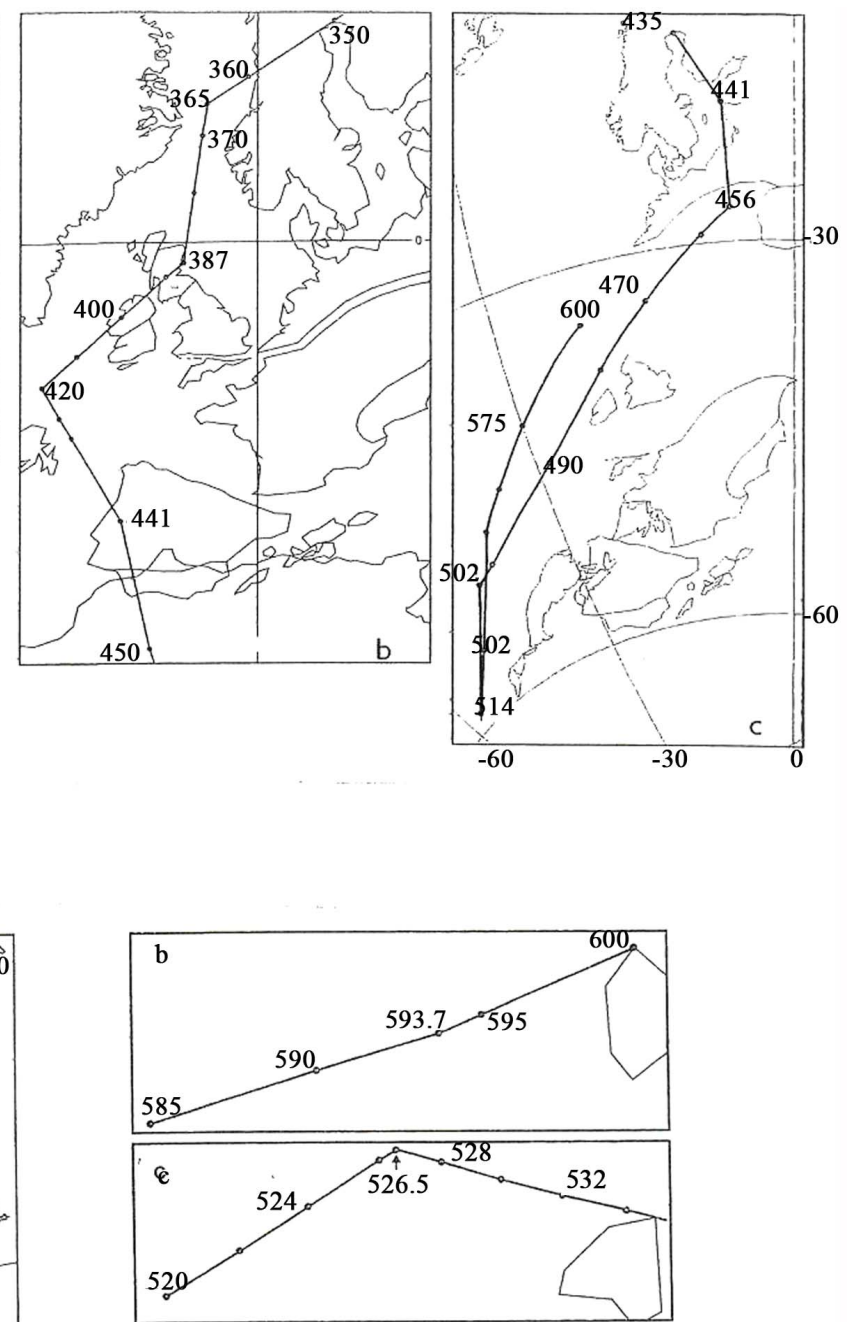

B

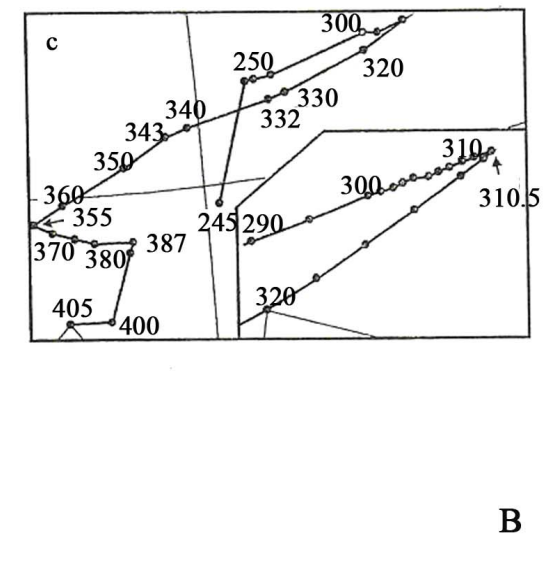

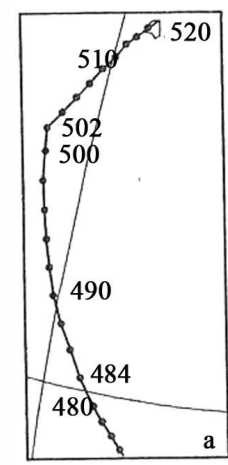

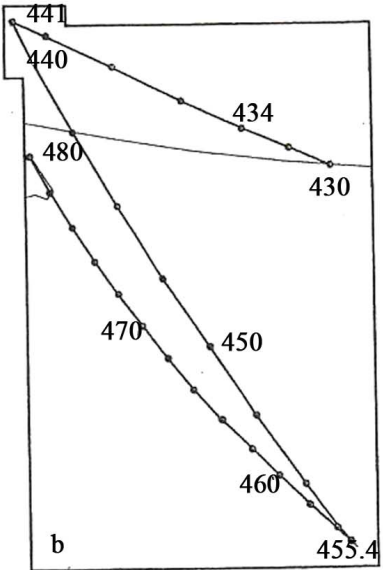

Figure 5. (A) Track of Fennoscandia from 600 - 250 Ma; (B) Track of Hawaii/Pacific realm from 600 - 245 Ma. 


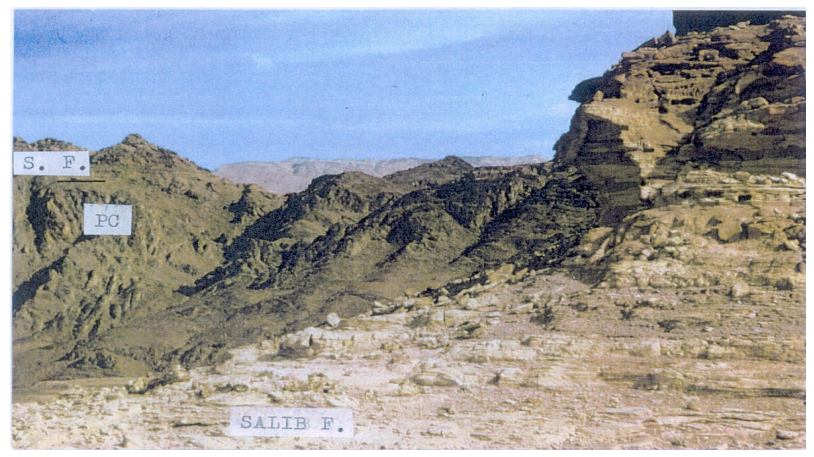

Figure 6. Precambrian magmatites overlain by immature arkosic molasse-sandstones of the Lower Cambrian Salib F., upper Wadi Abu Barqa, Wadi Araba.

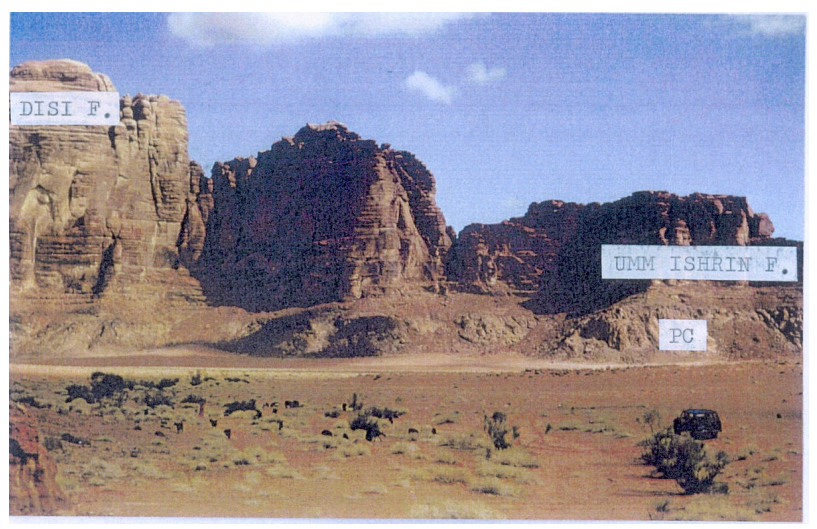

Figure 7. Precambrian basement (Pan-African magmatites: 625 - 600 Ma) overlain by Middle/Upper Cambrian red sandstones (Umm Ishrin F.) and white sandstones of the Late Cambrian/Lower Ordovician Disi F., Wadi Ram.

\subsubsection{Event: 514 Ma (F)}

In south-west Jordan there seems to be a remarkable coincidence of the transgressive base of the Burj F. (showing two MFS), overlying an uppermost Lower Cambrian paleosol, with the important Pre-Siq/Angudan Unconformity on the Arabian Plate, both fitting to 514 Ma. This is the onset of subsidence following peneplation on the Arabian Plate. The Burj F. is built up of two shale units interbedded with intertidal dolomites (Figure 8). Eastward, the shales and carbonates interfinger with shallow marine Abu Kusheiba-Sandstones [13].

On the Arabian Plate, an unconformity approximately marks the base of the Middle Cambrian (513 Ma) that falls onto the top of the lower shale unit of the Burj F. The top of the Burj F. overlain with sandstones of the Umm Ishrin F. may coincide with a MFS (Cm 20: 506 $\mathrm{Ma}$ ) on the Arabian Plate. For this period, major anoxic sedimentation on ocean floor around the Arabian Plate is assigned.

\subsubsection{Event: 502 Ma (P, F)}

In Jordan, there may be an intraformational "correlative conformity" (SB II: [9]) placed in the middle of the Late Cambrian, where the red sandstones of the Umm Ishrin F. are overlain by white sandstones of the Disi F. setting on abruptly with high detrital input (Figures 9 and 10).

On the Arabian Plate, that lithostratigraphic level lies

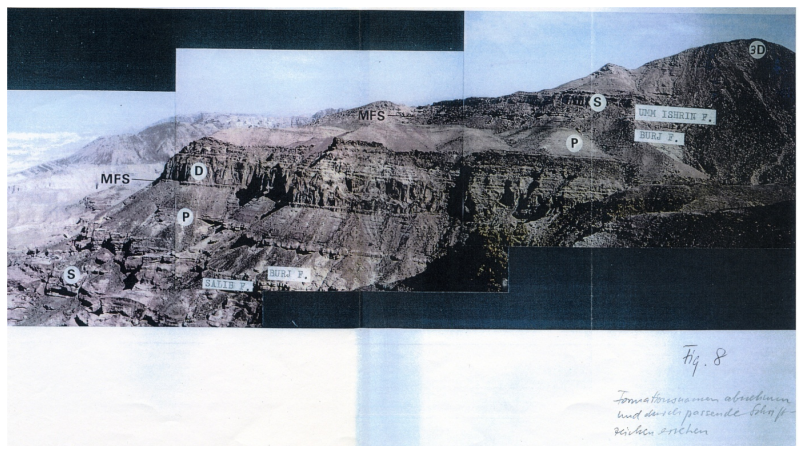

Figure 8. Cambrian section in the Nummeira area, southeastern end of the Dead Sea, consisting of sandflat facies (S), intertidal and lagoonal pelites (P), massive and slightly bedded shallow mecritic carbonates (D), mixed tidal flats bearing Rusophycus, lagoonal deposits (P), sandflats (S), and uppermost 3D megaripple facies (3D). Event: 502 Ma $(\mathbf{P}, \mathbf{F})$.

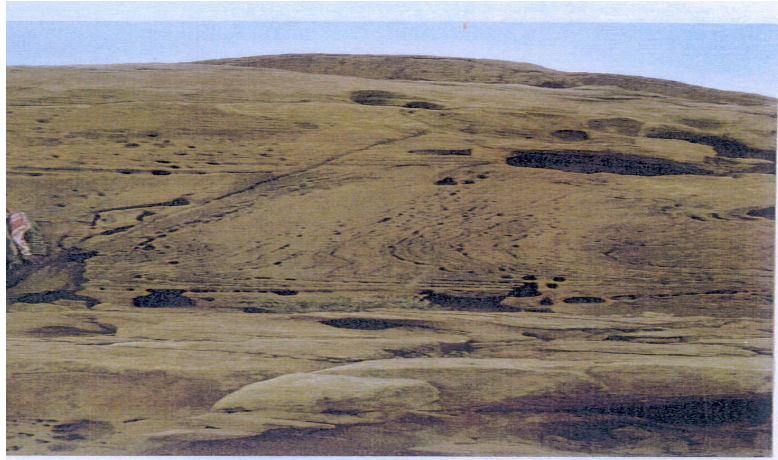

Figure 9. Dominating foresetting 3D megaripple sandstones of the Disi F. revealing overturned cross-bedding by high detrital input and high transport velocity, near type locality Disi village. Scale: B. S. Amireh.

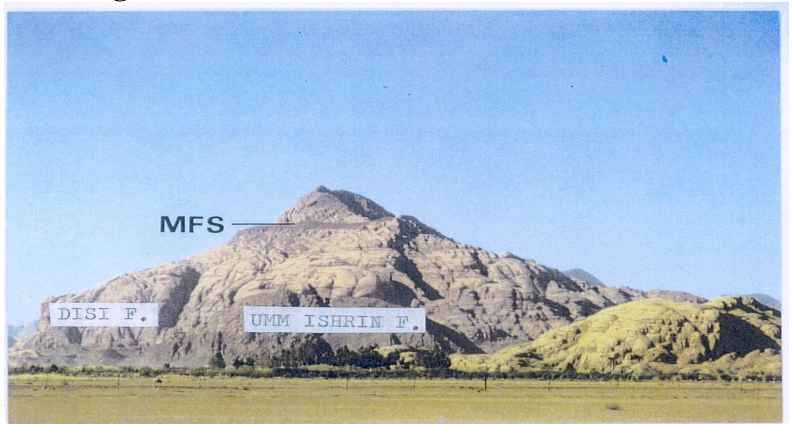

Figure 10. Jebel Amud west of Disi village: dark red sandstones of the Umm Ishrin F. overlain by white sandstones of the Disi F., upper part shows a MFS (red pelites bearing Cruziana furcifera of Lower Ordovician age). Uppermost cap of Jebel Amud consists of sandstone of the Umm Sahm F. 
close to an unconformity that coincides with the Middle/ Late Cambrian boundary (501 Ma) and an overlying MFS (496 Ma). Around that time-span, Paleozoic Gondwana finally assembled [5].

From the base of the Umm Ishrin F. up to the top of the Umm Sahm F., total disappearance of feldspar and a significant increase of kaolinite/dickite were recorded (Figure 11, [14]). That indicates extreme acid weathering conditions over a long period in the south-easterly located source areas on the Arabian Shield. Even the stable heavy mineral tourmaline shows extraordinary dissolution pat- tern (Figures 12 (a) and (b)).

\subsubsection{Events: 455 Ma (P), 456 Ma (F).}

The Dubaydib F./Tubeiliyat M. boundary of Jordan may approximately coincide with Price's data while on the Arabian Plate a MFS (040:454 Ma) immediately follows both events by oil-prone source rocks.

Furthermore, there appears a subordinate MFS in the upper part of the Dubaydib F. (Figure 13) and another one in the lower part of the Tubeiliyat M. (Figure 14) both representing green shales [15].

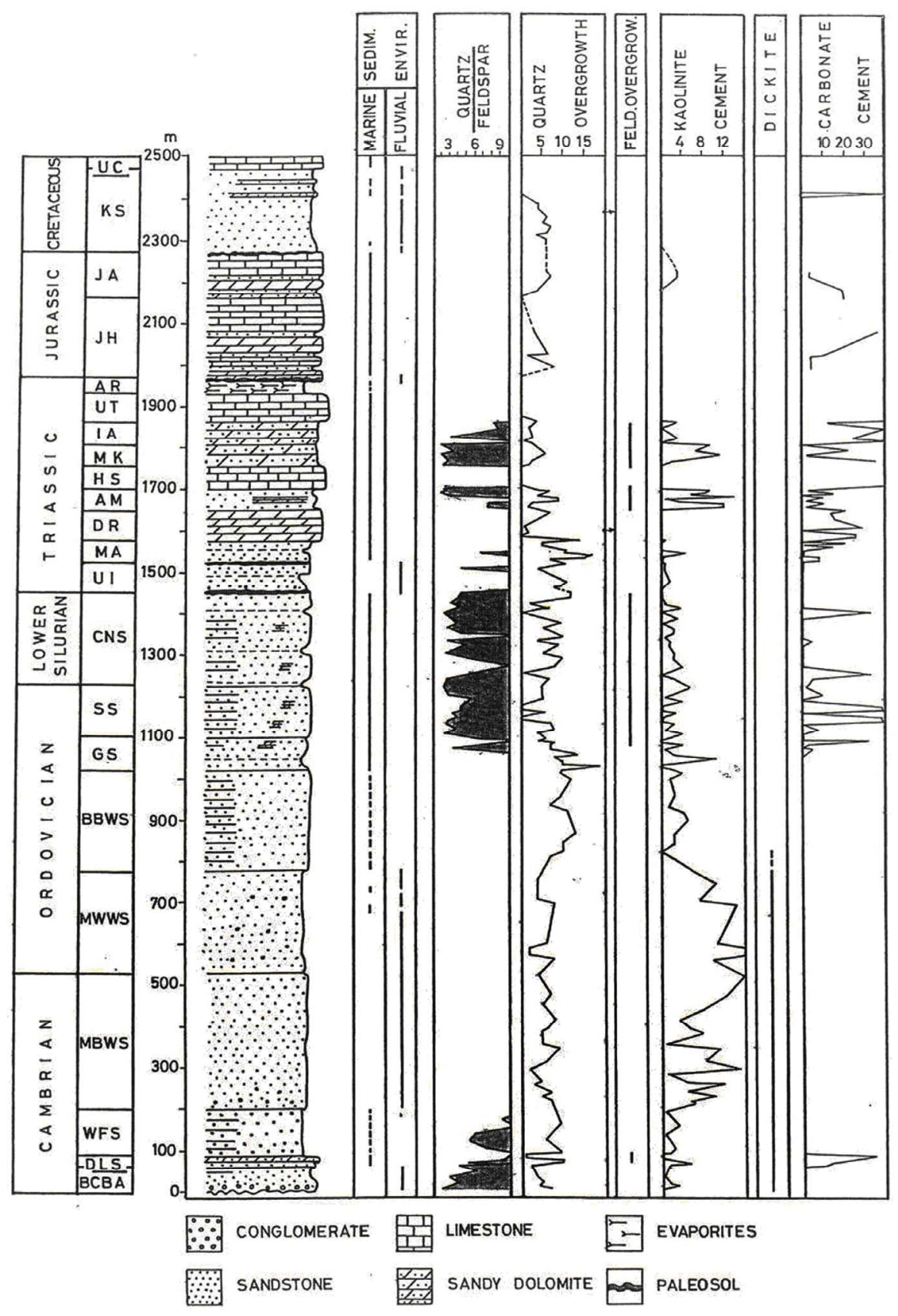

Figure 11. Mineral content variation throughout the Palaeozoic and Mesozoic sequences of Jordan. 


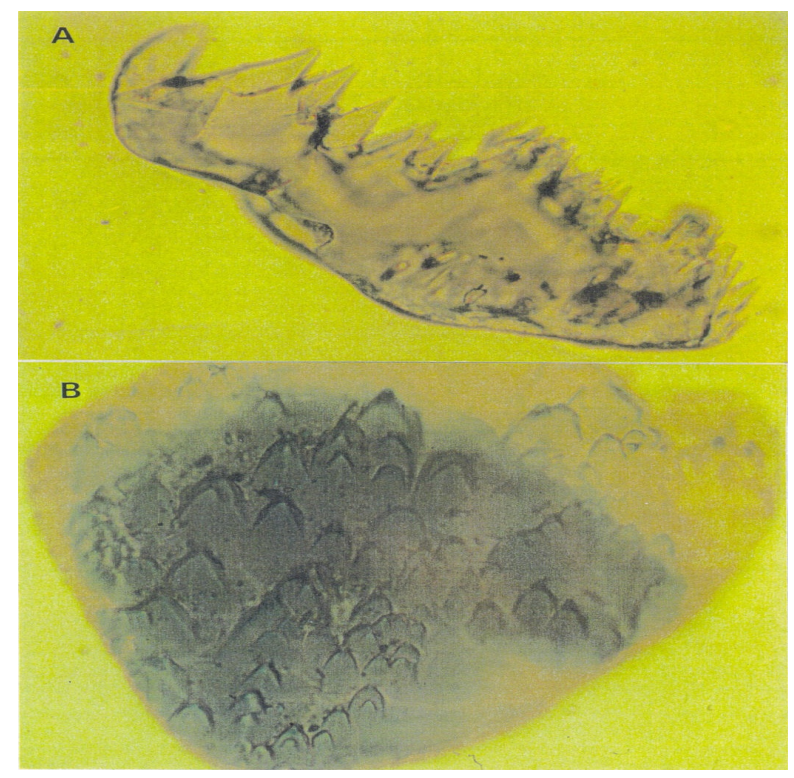

Figure 12. Tourmaline grains (diameter $0.2 \mathrm{~mm}$ ) showing unusual dissolution pattern (A) and etching figures (B), from a heavy mineral assemblage of the Disi $F$.

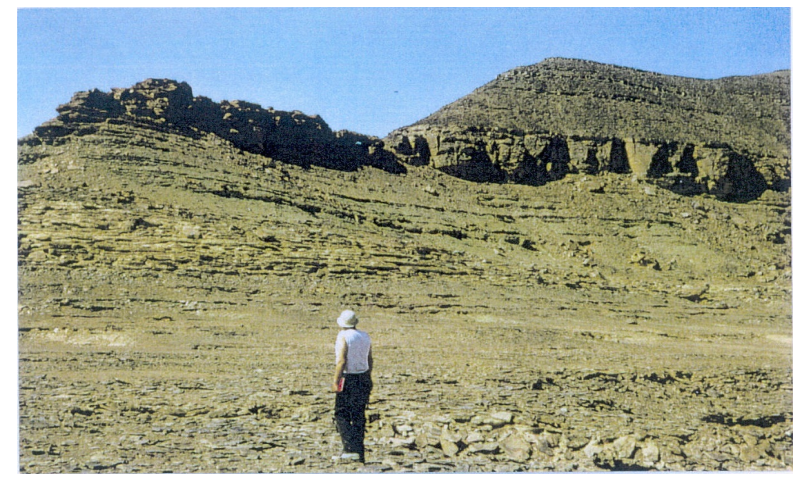

Figure 13. Subtidal channel filling sandstone unterlain and overlain by sandy shales at the Dubaydib F./Tubeiliyat M. boundery, south-eastern desert.

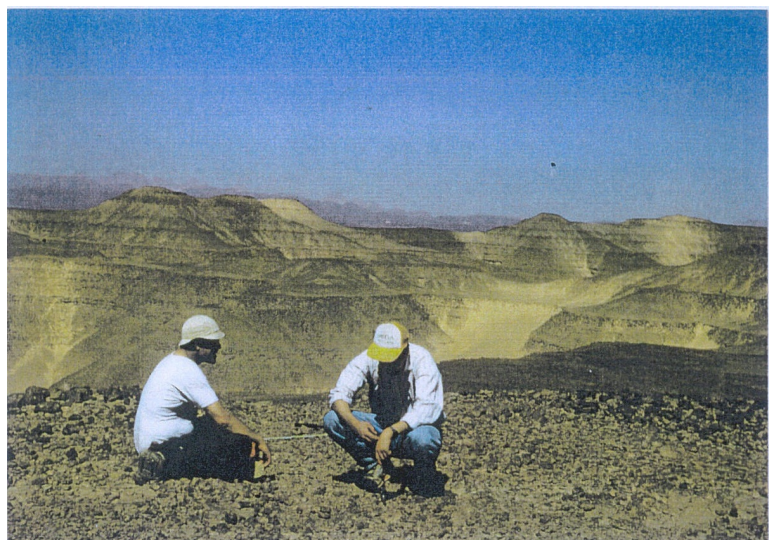

Figure 14. Typical landscape of the Tubeiliyat M. forming flat-topped mesas (sandy shales) and slightly inclined cuestas (Schichtstufen) built up by hummocky cross-stratified competed sandstones.

\subsubsection{Event: 441 Ma (F, P)}

In south-east Jordan, the Upper Ordovician exposes glacio-fluvial deposits (Ammar M./Mudawwara F.: Figure 15). This is according to the record on the Arabian Plate (AP 2/AP 3). Glaciation itself started on $446 \mathrm{Ma}$. At the Ordovician/Silurian boundary (443.7 Ma) brachiopodbearing transgressive shallow marine sandstones are overlain by black shales (Batra M.). According to Armstrong [16] in southern Jordan the Batra Shale set on in the uppermost Ordovician and is younging from southwest towards north-east. They interpret the top of the Batra Shale as MFS.

The Batra Shale can be correlated with the oil-prone shales of the Arabian Plate (MFS S 10: $440 \mathrm{Ma}$ ) that may coincide with Price's impact event.

Summarizing the data of this chapter (Table 2), there seems a remarkable coincidence of the age of sequenceanalytical data (MFS, SB) with the data of possible major impact events submitted by Price [10].

\section{Discussion}

"If we cannot improve our ability to establish synchroneity of phenomena and linkage with impacts, we likely will never be capable of identifying their effects in the sedimentary record. The paradox does not lie in the nature of things, but in our own procedural methodology. If so, the true relevance of bolide impacts to the sedimentary record is greater than is now, and possibly ever will be, realized," Clifton [2].

"On the other hand, there is a general difficulty in connecting impact ejecta horizons with possible source craters, in the face of an ever changing, and refinement of the geological time-scale [3,7] and the relatively poor chronological record for terrestrial impact structures (where many ages have errors of the order of $10 \mathrm{~s}$ of Ma or even more)," Reimold [3].

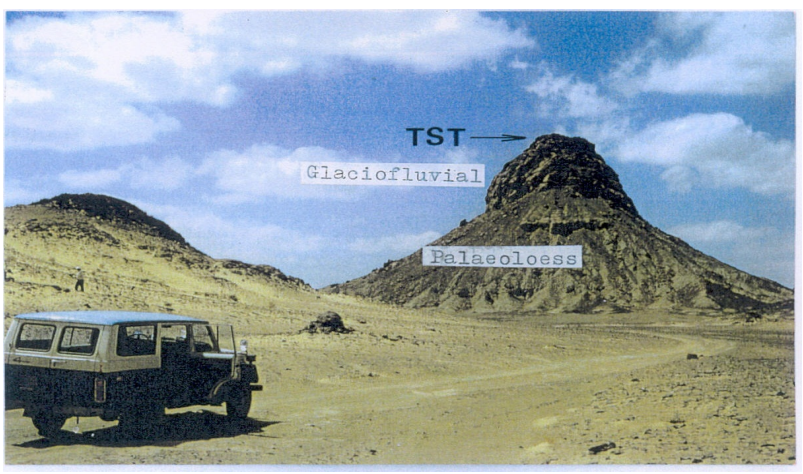

Figure 15. Jebel Ammar near Batu el Gul exhibiting palaeoloess deposits (lower part) overlain by glaciofluvial clastics bearing reworked faceted and striated pebbles at their base. At top, onsetting transgression (TST) with brachiopod-bearing sandstones transferring to black shales. Ammar $F$., south-eastern desert near Mudawwara. 
Relating to the sequence-analytical parameters of Figure 4, there is little possibility to find ejecta horizons throughout the early Palaeozoic systems of Jordan, but, rather, to encounter over-regional, even global, effects triggered by major impacts in terms of re-activation of labile faulting systems initiating magmatism, deposition of anoxic and high energy sediments, extremely high detrital input or extraordinary mineralogical and chemical variations of clastics in both source areas and depositional environments (comp.[17]: Figure 20).

Since impacts of large extraterrestrial bodies develop gigantic amounts of energy [3,17-21]: (Figure 11(b)) that may have world-wide influence, Jordan as located at the margin of the Arabian Plate, adjacent to the Jordan Valley Rift, and close to a triple junction (Figure 2), represents a "sensitive" geological setting with regard to convulsive events on globe that may initiate sea level changes, tsunamis, earthquakes, etc.

\subsection{Re-Activated Faulting Systems Triggering Magmatism}

Whether and up to what grade major impacts may cause magmatism has been broadly discussed throughout the last decades (e.g. [22]).

There is no doubt that major bolides would produce impact melts at impact location [3]. Furthermore, Price [10] postulates magma origination along important fault systems when such bolides hit the earth far away from the magmatic site, by causing a significant change of direction and speed of plate motions. That, in his opinion, concerns most of the extensive flood and plateau basalts on Earth. Negi et al. [23] interpret the Deccan Trap basalts as a result of impacting, too.

By application of Price's 550 Ma-Event to Jordan, this would coincide (within the realm of analytical error) with the Main Proterozoic Unconformity of the Pan-African Orogeny (550 Ma), and with the onset of the late bimodal volcanic/subvolcanic suite of Wadi Araba, Jordan Rift as well (550 - 540 Ma: [11,12]).

\subsection{Anoxic Sediments}

Major impacts may generally originate two types of oxygen-deficient sediments: (a) millimetre-thin soot-layers caused by wildfires of wide, even global, extension as encountered at the K/T-boundary [24-28] tremendous volumes of ash and dust migration in the atmosphere and stratosphere around the globe lasting for several months, interrupt accompanied by significant temperature decrease, the assimilation of green plants (photosynthesis) [29-32]. Consequently, huge amounts of organic matter, marine plankton, and algae decay and produce $\mathrm{C}_{\text {org }}$-rich sediments like black shales and bituminous carbonate rocks under varying $\mathrm{pH}-$, Eh-conditions.
Throughout Earth history, in many cases like, e.g. in the upper Palaeozoic of Central Europe, black shales frequently appear at the base of transgressions (MFS) on flat shelf platforms [33]. Focusing on the early Palaeozoic anoxic shales of Jordan, Arabian Plate, there may be coincidence with Price's Events at the following stratigraphic levels:

Price's 514 Ma-Event precedes immediately the base of the Burj-anoxic shales at Wadi Araba and on the Arabian Plate in general (513 Ma) that connects with the onset of subsidence following peneplation on the Arabian Plate. A major anoxic event on ocean floor is indicated for this period [5].

Price's 455.4/456 Ma-Event coincides with the Dubaydib F./Tubeiliyat M., boundary in Jordan and with oil-prone black shales on the Arabian Plate (MFS 040).

Price's 441 Ma-Event occurred when black shale deposition already took place in south-east Jordan [16]. It started shortly prior to the Silurian base (443.7 Ma) while, however, on the Arabian Plate the black shale (S 10: 440 $\mathrm{Ma})$ fits the impact date. At the time of black shale deposition indicated for extensive ocean floor areas [5] what happened during the South Hemisphere glaciations, Gondwana extended southward towards higher latitudes.

\subsection{Temporary High Detrital Input and Significant Mineralogic Change}

The deltaic sandstones of the Umm Ishrin F./Disi F. ranging in age from Late Cambrian to the Tremadoc/ Arenig boundary are, at some levels, extremely thickbedded, own overdimensial overturned cross-bedding (Figure 8), and a massive structure less occurrence [13,34]. They indicate high transport velocity, high sedimentation rates, and partly flash flood character. The Umm Ishrin F. some $350 \mathrm{~m}$ thick comprises $10 \mathrm{Ma}$ (Figure 4) and consequently an average sedimentation rate of $35 \mathrm{~mm} / 1000$ a. The Disi F., approximately $300 \mathrm{~m}$ thick and covering a period of $13 \mathrm{Ma}$, yields a rate of $23 \mathrm{~mm} / 1000$ a. That means that the sedimentation rates of temporary high energy transport and depositional processes were much higher which mainly concerns the Disi F.

The colour change from the (red) Umm Ishrin sandstone to the (white) Disi sandstone signals an abrupt change of weathering conditions. This lithostratigraphic level in Jordan coincides with a SB on the Arabian Plate and with Price's 502 Ma-Event (Figure 4). An explanation for extremely intensive rainfall can be given by the catastrophic weather conditions after a major impact [35, 36].

From the HST Cm 20 on (506 Ma), documented in Jordan by the Burj F./Umm Ishrin F. boundary, there occurs an abrupt disappearance of feldspar and an abrupt increase of kaolinite/dickite in the sandstone series (Figure 11, [14]). That indicates extremely low $\mathrm{pH}$-values of 
weathering solutions in both source areas and depositional environments as well, lasting until the next anoxic event (black shales of the Hiswah F.). As a heavy mineral grain, even tourmaline reveals extraordinary etching figures as solution pattern (Figure 11).

One might argue pore water of high acidity would be the reason. However, high feldspar contents in both underlying and overlying sandstone-series contradict.

Rather, one should encounter the reason in the source areas of the clastics and explain the extreme weathering conditions by intensive rain fall of high acidity. As Crutzen [37] Lewis [38] and Prinn \& Fegley [36] argued, the high acidic character of rain water can be explained by nitrogen acids originated via nitric oxides by an impact event. If we focus on Price's 514 Ma-Event, it could have the according influence throughout $8 \mathrm{Ma}$ in order to bring this extremely high acidic weathering over the granitoid rocks exposed in the south-east-located Gondwana hinterlands.

\section{Conclusions}

"The 'Rare Event' in Geology is defined as a spasm, episode or punctuation of such a low rate of occurrence that it has taken place at most a few times through all of Earth History. There is no known physical law that permits to relegate such highly improbable events into the realm of the impossible [1]". Since then, geoscientists more frequently assume major impacts than expressed in this quotation. Nevertheless, the only impact crater certain throughout the Phanerozoic, originated from the K/T-impact-event at Chicxulub crater, Mexico, though mass extinctions at several formation boundaries may give evidence on further convulsive events [3,17].

If it could be pointed out that Price's concept would be wrong or not solid enough to meet all scientific requirements, this paper would just represent a scientific game. Furthermore, if the analytical error of the radiometric data of both Price [10] and Haq \& Al-Qahtani [5] does not own the necessary exactness, it would, in turn, underline its scientific game character. Though Haq \& AlQahtani's [5] data of the Arabian Plate are based on a high density and reliability of exploration, even an analytical error of \pm 0.5 Ma would give no definite certainty of impact-relating to the sequence-analytical record (MFS, SB). However, the more fold dense approach to coincidence cannot be only a lucky chance. That means we, in this case, are facing a geoscientific "boundary dispute".

Accepting the methodology applied, a "rigid scientist" sensu Gretener does face a problem. His attitude would mean refusing the opening of new windows towards the future of Geosciences. Opening and non-opening of such windows obviously depends on personality $[39,40]$. Finding ejecta horizons throughout the Paleozoic seems unprobable because of erosion, reworking, resedimenta- tion, weathering, diagenesis etc., except within basins owning continuous subsidence, high sedimentation rates, and low chemical diagenesis for preservation.

Finally, there cannot be any doubt that major impacts may have influence on exogenic and endogenic geologic processes with regard to over-regional, even global, extension far away from the impact site (see references in Chapter 3).

Hence, summarizing reasonable impact/sequence-analytical data relationship through the early Paleozoic of Jordan as a "sensitive" setting at the margin of the Arabian Plate, close to the Jordan Valley Rift and to an Early Paleozoic triple junction, the following can be stated:

1) Faulting and magmatism at and after the $550 \mathrm{Ma}-$ Event at Wadi Araba.

2) Anoxic sediments coincide with Price's impact data in Jordan and the Arabian Plate at all (oil-prone source rocks, MFS), like: Burj F. base (513 Ma), Dubaydib F./ Tubeiliyat M. boundary (454 Ma), and Ordovician/Silurian boundary (440 Ma). However, the Hiswah F. black shale does not show any correlation to one of Price's impact Events.

3) Onset of temporary high detrital input by intensive rain fall starting at the base of the Disi F. (496 Ma) after the 502 Ma-Event.

4) Significant disappearance of feldspar, high increase of kaolinite/dickite, and extreme solution pattern in sandstones (e.g. tourmaline) by acid (nitric) intensive rain fall in the source areas after the 526.5 Ma- and the 514 MaEvent.

\section{Closing Statement}

"Da im Raster der naturwissenschaftlichen Disziplinen nur Wirkungen zugelassen werden, scheint es so, als müssten wir etwas ganz Seltenes, Entlegenes aufspüren, wenn wir 'Auswirkungen' suchen. Der Trick der Wissenschaft besteht darin, auch den Beweis nur in der Form der logischen Aufweisung, also im Horizont der Wirkungsketten, zuzulassen. Dann können natürlich "Auswirkungen” nie bewiesen werden, und die Vorhersage, "Auswirkungen” gäbe es gar nicht, hat die Form einer sich selbst erfüllenden Prophezeiung” [41].

Opposing Price's impact event data with important mass extinctions occurred throughout the Early Paleozoic Period (Figure 16), in every case an approximate age coincidence between both can be stated. Thus, somewhat like a "rendez-vous" of all three striking sedimentologic pattern, mass extinction and Price's impact data may be verified in every case of event within the realm of this geologic "boundary dispute".

Even the anoxic Hiswah F. (469 Ma) which does not show any correlation to Price's impact event data, corresponds with one of the significant mass extinctions (Figure 16). 


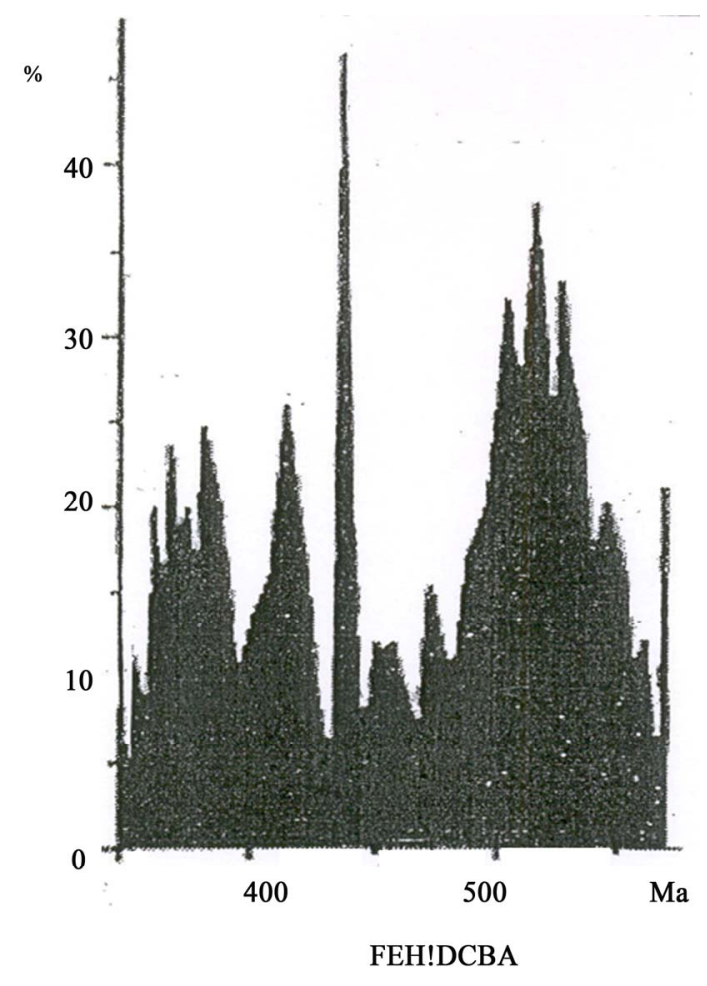

Figure 16. Mass extinctions (genus extinction in per cent) throughout the early Palaeozoic period after Stöffler (2002: Figure 23). Letters A - F refer to Price's impact event data.

\section{Dedication and Acknowledgements}

Dedicated to Prof. Dr. Wolf von Engelhardt. The author is indebted to the colleagues of the Department of Geology, Jordan University, Amman and to N.R.A., Amman for 30 years fruitful co-operation. Thanks to the chief editor of "GeoArabia", M. Husseini, who already has allowed use of Figure 2 on the left column of Figure 4 of the former paper (2007). I do appreciate the support of H.-G. Röhling, Hannover, and Mrs. H. Moltrecht, Groß-burgwedel, for bringing the manuscript into the digital version. Finally, I would like to emphasize the warm welcome of many local Bedouins and villagers through three decades of wonderful fieldwork.

\section{REFERENCES}

[1] P. E. Gretener, "Reflections on the 'Rare Event' and Related Concepts in Geology,” University of Calgary, Calgary, 1978.

[2] H. E. Clifton, "Sedimentologic Relevance of Convulsive Geologic Events,” Energy Citations Database, Vol. 229, 1988, pp. 1-5.

[3] W. U. Reimold, "Revolutions in the Earth Sciences: Continental Drift, Impact and Other Catastrophes: The 29th De Beers Memorial Lecture," South African Journal of Geology, Vol. 110, 2007, pp. 1-46. doi:10.2113/gssajg.110.1.1
[4] P. R. Sharland, R. Archer, et al., "Arabian Plate Sequence Stratigraphy,” GeoArabia Specific Publications, Bahrain, 2001.

[5] B. U. Haq and A. M. Al-Qahtani, "Phanerozoic Cycles of Sea-Level Change on the Arabian Platform,” GeoArabia, Vol. 10, No. 2, 2005, pp. 127-160.

[6] W. Schneider, B. S. Amireh and A. M. Abed, "Sequence Analysis of the Early Paleozoic Sedimentary Systems of Jordan,” Zeitschrift der Deutschen Gesellschaft Für Geowissenschaften, Vol. 158, No. 2, 2007, pp. 225-247.

[7] M. I. Husseini, "Tectonic and Depositional Model of Late Precambrian-Cambrian Arabian and Adjoining Plates,” American Association of Petroleum Geologists Bulletin, Vol. 73, No. 9, 1989, pp. 1117-1131.

[8] W. E. Galloway, “Genetic Stratigraphic Sequences in Basin Analysis, I: Architecture and Genesis of Flooding Surface Bounded Depositional Units,” American Association of Petroleum Geologists Bulletin, Vol. 73, 1989, pp. 125-142.

[9] P. R. Vail, et al., "Seismic Stratigraphy and Global Changes of Sea Level,” In: C. E. Payton, Ed., Seismic stratigraphy-Applications to Hydrocarbon Exploration, American Association of Petroleum Geologists, Tulsa, 1977, pp. 49-212.

[10] N. J. Price, “Major Impacts and Plate Tectonics,” Routledge, London, 2001.

[11] G. Jarrar, H. Wachendorf and D. Zachmann, "A PanAfrican Alkaline Pluton Intruding the Saramuj Conglomerate, Southwest Jordan,” Geologische Rundschau, Vol. 82, No. 1, 1993, pp. 121-135. doi:10.1007/BF00563275

[12] G. Jarrar, H. Wachendorf and G. Saffarini, "A Late Proterozoic Bimodal Volcanic/Subvolcanic Suite from Wadi Araba, Southwest Jordan,” Precambrian Research, Vol. 56, No. 1-2, 1992, pp. 51-72. doi:10.1016/0301-9268(92)90083-Z

[13] B. S. Amireh, W. Schneider and A. M. Abed, "Evolving Fluvial-Transitional-Marine Deposition through the Cambrian Sequence of Jordan,” Sedimentary Geology, Vol. 89, No. 1-2, 1994, pp. 65-90. doi:10.1016/0037-0738(94)90084-1

[14] B. S. Amireh, W. Schneider and A. M. Abed, "Diagenesis and Burial History of the Cambrian-Cretaceous Sandstone Series in Jordan,” Neues Jahrbuch Fuèr Geologie und PalaÈontologie Abhandlung, Vol. 192, No. 2, 1994, pp. 151-181.

[15] L. M. Makhlouf, “Depositional Environments and Facies in the Dubaydib and Tubeiliyat Sandstones, Southern Desert, Jordan,” Subsurface Geology, Bulletin 3, Natural Resources Authority, Amman, 1992, pp. 1-28.

[16] H. Armstrong, et al., “Origin, Sequence Stratigraphy and Depositional Environment of an Upper Ordovician (Hirnantian) Deglacial Black Shale, Jordan,” Palaeogeography, Palaeoclimatology, Palaeoecology, Vol. 220, No. 3-4, 2005, pp. 273-289. doi:10.1016/j.palaeo.2005.01.007

[17] D. Stöffler, "Bedrohung Aus Dem Weltall-Asteroiden und Kometen,” In: R. Emmermann, Ed., An den Fronten der Forschung, Kosmos-Erde-Leben, Verhandl. Ges. dt. Naturforscher und Ärzte, Halle, 2002. 
[18] W. von Engelhardt, "Die Bildung von Kratern Durch den Aufprall Extraterrestrischer Massen,” Naturwissenschaften, Vol. 61, No. 9, 1974, pp. 380-395.

[19] S. V. M. Clube and W. M. Napier, "The Role of Episodic Bombardement in Geophysics," Earth and Planetary Science Letters, Vol. 57, No. 2, 1982, 251-262. doi:10.1016/0012-821X(82)90148-0

[20] S. V. M. Clube and W. M. Napier, "The Cosmic Serpent, A catastrophyst View of Earth History,” Faber \& Faber, London, 1982.

[21] P. J. Burek and H. Wänke, "Impacts and Glacio-Eustatic, Plate Tectonic Episodes, Geomagnetic Reversals,” Physics Earth Planetary Interiors, Vol. 50, No. 2, 1988, pp. 183-194. doi:10.1016/0031-9201(88)90005-2

[22] R. B. Stothers and M. R. Rampino, "Periodicity in Flood Basalts, Mass Extinctions and Impacts," Special Paper-Geological Society of America, Vol. 247, 1990, pp. 9-18.

[23] J. Negi, P. Agrawal, O. Pandey and A. Singh, “A possible K-T Boundary Bolide Impact Site Offshore Bombay and Triggering of Rapid Deccan Volcanism,” Physics of Earth and Planet, Vol. 76, 1993, pp. 189-197.

[24] W. S. Wolbach, R. S. Lewis, et al., "Cretaceous Extinctions: Evidence for Wildfires and Search for Meteoritic Material," Science, Vol. 230, No. 4722, 1985, pp. 167170. doi:10.1126/science.230.4722.167

[25] W. S. Wolbach, I. Gilmour, et al., "Major wildfires at the Cretaceous boundary,” Special Paper-Geological Society of America, Vol. 247, 1988, pp. 391-400.

[26] K. J. Hsü, “Cretaceous/Tertiary Boundary Sediment,” In: H. E. Clifton, Ed., Sedimentologic Consequences of Convulsive Geologic Events, Special Paper-Geological Society of America, Boulder, 1988.

[27] I. Gilmour, W. S. Wolbach, et al., "Major Wildfires at the Cretaceous/Tertiary Boundary,” In: S. V. M. Clube, Ed., Catastrophes and Evolution, Boulder, 1990.

[28] I. Gilmour, W. S. Wolbach, et al., "Early Environmental Effects of the Terminal Cretaceous Impact," Special Paper-Geological Society of America, Vol. 247, 1990, pp. 283-390.

[29] J. B. Pollack, O. B. Toon, et al., "Environmental Effects of an Impact-Generated Dust Cloud: Implications for the Cretaceous-Tertiary Extinction,” Science, Vol. 219, No. 4852, 1983, pp. 287-289. doi:10.1126/science.219.4582.287
[30] O. B. Toon, "Sudden Changes in Atmospheric Composition and Climate,” In: H. D. Holland and A. F. Trendall, Eds., Pattern in Change of Earth Evolution, Springer, Berlin, 1984, pp. 41-61.

[31] H. Flohn, "Singular Events and Catastrophes Now and in Climatic History,” Naturwissenschaften, Vol. 73, No. 3, 1986, pp. 136-149. doi:10.1007/BF00367402

[32] C. R. Chapman and D. Morrison, "Cosmic Catastrophes VIII,” Plenum Press, London, 1989.

[33] W. Krebs, "Über Schwarzschiefer und Bituminöse Kalke im Mitteleuropäischen Variscikum,” Erdöl und Kohle, Hamburg, Vol. 22: No. 2-6, 1969, pp. 62-67.

[34] B. S. Amireh, W. Schneider and A. M. Abed, "FluvialShallow Marine-Glaciofluvial Depositional Environments of the Ordovician System of Jordan,” Journal of Asian Earth Science, Vol. 19, No. 1-2, 2001, pp. 45-60. doi:10.1016/S1367-9120(00)00010-9

[35] S. K. Croft, "A First-Order Estimate of Shock Heating and Vaporization in Oceanic Impacts,” Special PaperGeological Society of America, Vol. 190, 1982, pp. 143152.

[36] R. G. Prinn, and J. B. Fegley, "Bolide Impacts, Acid Rain, and Biospheric Traumas at the Cretaceous-Tertiary Boundary," Earth and Planetary Science Letters, Vol. 83, No. 1-4, 1987, pp. 1-15. doi:10.1016/0012-821X(87)90046-X

[37] P. J. Crutzen, “Acid Rain at the K/T Boundary,” Nature, Vol. 330, 1987, pp. 108-109. doi:10.1038/330108a0

[38] J. S. Lewis, G. H. Watkins, et al., "Chemical Consequences of Major Impact Events on Earth,” Special Paper-Geological Society of America, Vol. 190, 1982, pp. 215-221.

[39] I. L. Janis, et al., "Personality and Persuasibility-New Haven,” In: R. Saudek, Spearman, E. K. Ch. and K. E. Zener, Eds., Journal of Personality, Duke University Press, Durham, 1979.

[40] H. Menzel, "Planned and Unplanned Scientific Communication," Proceedings of the International Conferences on Scientific Information, National Academy of Sciences, Washington DC, 1959, pp. 199-243.

[41] A. M. K. Müller, "Interdisziplinäre Forschung Als Geschichtliche Herausforderung," Pressestelle der Universität Hamburg, Hamburg, 1991. 